\title{
Stress analysis for mandibular screw retained full arch prosthesis, all in 4 concept, with different cantilever extension.
}

Moaz Mostafa Farrag ( $\sim$ moazfarrag89@gmail.com )

Faculty of Dentistry , Cairo University

Method Article

Keywords: stress , analysis,prosthesis,cantilever,dental

Posted Date: June 17th, 2019

DOl: https://doi.org/10.21203/rs.2.10205/v1

License: (c) (i) This work is licensed under a Creative Commons Attribution 4.0 International License.

Read Full License 


\section{Abstract}

Compare the stress distribution pattern in two different cantilever length in mandibular screw retained prosthesis by computing the distribution of stresses in Bone/implant interface in different zone, magnitude and Direction of force applied using finite element analysis software.

\section{Introduction}

The main objective of this study is to Compare the stress distribution pattern in two different cantilever length in mandibular screw retained prosthesis by computing the distribution of stresses in Bone/implant interface in different zone, magnitude and Direction of force applied using finite element analysis software

\section{Reagents}

1. Prof.Dr . Hamdi Abo Alfotoh (Main supervisor) $\otimes$ Professor in department of removable prosthodontics- Cairo university $\square$ Main supervisor $\square$ Responsible for data auditing, study selection , and Data monitoring

2. Dr . Doaa Amr (co-supervisor): $\mathbb{Q}$ Lecturer in department of removable prosthodontics- Cairo university $\square$ Co-supervisor $\triangle$ Responsible for data auditing, and Data monitoring

\section{Equipment}

3D Object modeling

Finite element analysis software

\section{Procedure}

Calculated sample size

Eligibility criteria

Intervention :

-In the control group: Edentulous mandible will be restored with screw retained overdenture by four implants with $10 \mathrm{~mm}$ cantilever length . - In intervention group: Edentulous mandible will be restored with overdentures retained by four implants with $16 \mathrm{~mm}$ and $20 \mathrm{~mm}$ cantilever .

Meshing

Defending the material properties 


\section{Troubleshooting}

\section{Time Taken}

\section{Anticipated Results}

Stress distribution in implant \bone interface

\section{References}

1. Satti, A.A., Comparison of Retentive properties of two Attachment Systems in Mandibular Overdentures-An in vitro study. 2013. 2. El-Anwar, M.I., et al., A finite element study on stress distribution of two different attachment designs under implant supported overdenture. The Saudi dental journal, 2015. 27(4): p. 201-207. 3. Feine, J.S., et al., The McGill consensus statement on overdentures. Mandibular two-implant overdentures as first choice standard of care for edentulous patients. Montreal, Quebec, May 24-25, 2002. Int J Oral Maxillofac Implants, 2002. 17(4): p. 601-2. 4. Greenstein, G., J.R. Carpentieri, and J. Cavallaro, Nerve damage related to implant dentistry: incidence, diagnosis, and management. Compend Contin Educ Dent, 2015. 36(9): p. 652-9. 5. Fitzpatrick, B., Standard of care for the edentulous mandible: a systematic review. The Journal of prosthetic dentistry, 2006. 95(1): p. 71-78. 6. Bakke, M., B. Holm, and K. Gotfredsen, Masticatory function and patient satisfaction with implantsupported mandibular overdentures: a prospective 5-year study. International Journal of Prosthodontics, 2002. 15(6). 7. Doundoulakis, J.H., et al., The implant-supported overdenture as an alternative to the complete mandibular denture. The Journal of the American Dental Association, 2003. 134(11): p. 14551458. 8. Bidez, M. and C. Misch, Clinical biomechanics in implant dentistry. 2005. 9. Sadowsky, S.J. and A.A. Caputo, Stress transfer of four mandibular implant overdenture cantilever designs. The Journal of prosthetic dentistry, 2004. 92(4): p. 328-336. 10. Taruna, M., et al., Prosthodontic perspective to all-on-4® concept for dental implants. Journal of clinical and diagnostic research: JCDR, 2014. 8(10): p. ZE16. 11. Rodriguez, A.M., S.A. Aquilino, and P.S. Lund, Cantilever and implant biomechanics: a review

\section{Acknowledgements}

\section{Supplementary Files}

This is a list of supplementary files associated with this preprint. Click to download.

- supplement1.pdf 